\title{
Radiographic inspection of porosity in Ti-6Al-4V laser-welded joints
}

\author{
Juliana Maria Costa Nuñez- \\ Pantoja $^{(a)}$ \\ Jessica Mie Ferreira Koyama \\ Takahashi(a) \\ Mauro Antônio de Arruda \\ Nóbilo(a) \\ Rafael Leonardo Xediek Consani(a) \\ Marcelo Ferraz Mesquita(a)
}

(a) Department of Prosthodontics and Periodontology, Piracicaba Dental School, University of Campinas, Piracicaba, SP, Brazil.
Corresponding author:

Juliana Maria Costa Nuñez-Pantoja

Travessa Dona Eugênia, 135, apto. 71

Piracicaba - SP - Brazil

CEP: 13416-218

E-mail: julynunez@terra.com.br

Received for publication on Sep 21, 2010 Accepted for publication on Dec 06, 2010
Abstract: Widely used in dentistry, Ti-6Al-4V alloy is difficult to cast and solder, as it frequently exhibits pores inside the structure. This study was conducted to evaluate the effect of joint openings and diameters of laser-welded joints executed in Ti-6Al-4V structures on the presence of pores as checked by radiographic procedures. Sixty dumbbell rods with central diameters of 1.5, 2.0 and $3.5 \mathrm{~mm}$ were created from Ti-6Al-4Vwrought bars. Specimens were sectioned and welded using two joint openings $(0.0$ and $0.6 \mathrm{~mm})$. The combination of variables created six groups $(\mathrm{n}=10)$. Laser welding was executed using $360 \mathrm{~V} / 8 \mathrm{~ms}$ (1.5 and $2.0 \mathrm{~mm})$ and $380 \mathrm{~V} / 9 \mathrm{~ms}(3.5 \mathrm{~mm})$, with the focus and frequency set to zero. The joints were finished, polished and submitted to radiographic examination. The radiographs were visually examined for the presence of pores in the joints, qualitatively. The percentage of radiographic presence of pores was calculated without counting pores per joint. Data were analyzed using a chi-square test $(\alpha=0.05)$. For the $1.5-\mathrm{mm}$ specimens, the incidence of pore presence was significantly higher $(\mathrm{p}=0.0001)$ when using $0.6-\mathrm{mm}$ joint openings $(40 \%)$ compared to $0.0-\mathrm{mm}$ openings $(0 \%)$. For the $2.0-\mathrm{mm}$ specimens, there was no significant difference between groups $(\mathrm{p}=0.2008)$. However, for the $3.5-\mathrm{mm}$ specimens, the incidence of pore presence was lower $(\mathrm{p}=0.0061)$ for $0.6-\mathrm{mm}$ openings $(50 \%)$ compared to $0.0-\mathrm{mm}$ openings $(70 \%)$. Therefore, laser welding of $\mathrm{Ti}^{-}$ $6 \mathrm{Al}-4 \mathrm{~V}$ structures with thin diameters provides the best condition for the juxtaposition of the parts.

Descriptors: Titanium; Dental Soldering; Radiography, Dental; Dental Alloys.

\section{Introduction}

Titanium alloys have been used for many years in the manufacturing of aerospace products and in marine service. However, they have only been utilized in dental applications over the last two decades. ${ }^{1}$ From an industrial perspective, titanium alloys are attractive due to their low specific gravity, high strength-to-weight ratio, fatigue and corrosion resistance, ${ }^{1,2}$ and biocompatibility, which is important in dentistry. Titanium alloys possess many of the clinically favored properties of type-III and type-IV gold dental alloys at a lower cost. The Ti-6Al-4V alloy is the most commonly used titanium alloy in dentistry. ${ }^{3}$ Dental alloys containing nickel, chromium, cobalt and aluminum can cause hypersensitivity reactions and can be associated with allergy in sensitive patients. ${ }^{4,5} \mathrm{Nev}$ - 
ertheless, $\mathrm{Ti}-6 \mathrm{Al}-4 \mathrm{~V}$ is the material used to create the prosthetic components used in implant prostheses by companies that manufacture dental implants. Moreover, in cytotoxicity studies, Ti-6Al-4V was not found to be cytotoxic to epithelial cells. ${ }^{5}$

Passive fit to osseointegrated implants and modifications or repairs to fractured titanium alloy frameworks can be achieved with the laser welding procedure. ${ }^{1,6}$ Welding involves a metallurgical joining process that relies on the fusion of base metals, with or without metal filler, for the formation of the joint. ${ }^{7-9}$ Titanium alloys are difficult to cast and solder due to their high melting points and strong affinity for gases, such as oxygen, hydrogen and nitrogen. ${ }^{10,11}$ Consequently, specific equipment that employs an argon shield in the welding chamber is required to solder titanium alloy frameworks. ${ }^{6,12-14}$

Reports suggest that the laser welding technique creates a smaller heat-affect zone (HAZ), reduced distortion in the framework, and less damage to the veneer coverage as compared to the brazing procedure. ${ }^{3,6,7}$ In addition, results of studies have demonstrated that laser-welded joints present yield strengths close to those of base metals under static conditions. ${ }^{3,6,7}$ However, results of several studies investigating the laser welding of titanium and titanium alloys have also shown increased hardness in the welded zone and the presence of large pores in the laser-repaired joints. ${ }^{13-15}$

The joint's design also directly affects its level of resistance. ${ }^{15}$ The laser beam cannot penetrate to the center of structures with large diameters with an "I" design. ${ }^{7,13,15}$ In structures with thin diameters, the resistance to mechanical cycling is lower when there is no juxtaposition of parts in an "I" design due to gas arrestment during the addition of metal used to fill the gap. ${ }^{15}$

To investigate porosity within titanium structures, a simple method developed by Wang and Boyle ${ }^{16}$ may be utilized. In the process, the framework is exposed to radiation $(90 \mathrm{KV}, 25 \mathrm{~mA}, 30$ seconds, at a distance of $10 \mathrm{~mm}$ ) using occlusal film. In 2001, Zavanelli and Henriques ${ }^{17}$ described a similar method in which titanium was exposed to radiation $(90 \mathrm{KV}, 15 \mathrm{~mA}, 0.6$ seconds, at a distance of 10 to $13 \mathrm{~mm})$. The low density $\left(4.2 \mathrm{~g} / \mathrm{cm}^{3}\right)$ of tita- nium allows investigators to use this routine dental radiography to investigate porosity in frameworks, internal defects in specimens to be tested, or secondary caries below crowns made in titanium. ${ }^{16-18}$ This method highlights internal defects that could not be seen by the naked eye, which is an important advantage. Some large casting defects can only be found in the internal structure of the casting and have been camouflaged numerous times by the outer limits of accuracy. ${ }^{18}$ Using these radiographic methods, many authors have observed the internal porosity in titanium castings ${ }^{10,18}$ and laser-welded joints. ${ }^{15}$

The aim of this study was to evaluate the influence of the design of laser-welded joints, including the size of joint openings and diameters of the cross section, executed in Ti-6Al-4V structures by checking the percentage of porosity present using radiographic procedures. The hypothesis was that the juxtaposition of parts would influence the percentage of radiographic porosity present, depending on the diameter of the joints.

\section{Material and Methods}

Sixty dumbbell-shaped rods were machined, using Ti-6Al-4V grade 5 rods (Neodent; Curitiba, Brazil) based on norm ASTM E8M- $04^{19}$ with diameters of 1.5, 2.0 and $3.5 \mathrm{~mm}$ in the central segment (Figure 1). These rods were selected because it is from them that prosthetic components used in implant prostheses are machined by companies that make dental implants. Dumbbell rods were sectioned in half perpendicularly to the long axis. Further, the two sectioned parts were lined up in a metal matrix in order to maintain joint openings of 0.0 and $0.6 \mathrm{~mm}$.

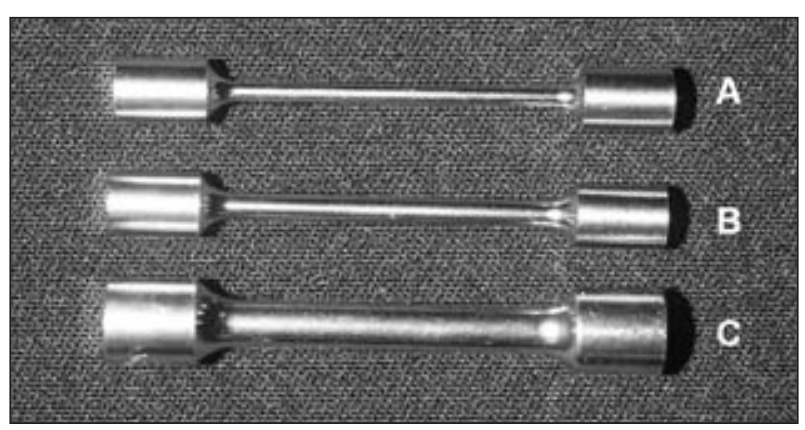

Figure 1 - Test specimens. A: diameter of $1.5 \mathrm{~mm}$, B: diameter of $2.0 \mathrm{~mm}$, C: diameter of $3.5 \mathrm{~mm}$. 
The diameters and joint openings were selected to simulate the following situations:

1. central diameter of $1.5 \mathrm{~mm}$ : three-element fixed prosthesis frameworks,

2. central diameter of $2.0 \mathrm{~mm}$ : overdenture bars,

3. central diameter of $3.5 \mathrm{~mm}$ : ten-element fixed prosthesis frameworks,

4. joint opening of $0.0 \mathrm{~mm}$ : precast cut, and

5. joint opening of $0.6 \mathrm{~mm}$ : cut with a thin disc.

The combination of the variables (diameters and joint openings) resulted in six groups $(n=10)$ :

- $\mathrm{G}_{1}=$ central diameter of $1.5 \mathrm{~mm}$ and $0.0-\mathrm{mm}$ joint openings,

- $\mathrm{G}_{2}=$ central diameter of $1.5 \mathrm{~mm}$ and $0.6-\mathrm{mm}$ joint openings,

- $\mathrm{G}_{3}=$ central diameter of $2.0 \mathrm{~mm}$ and $0.0-\mathrm{mm}$ joint openings,

- $\mathrm{G}_{4}=$ central diameter of $2.0 \mathrm{~mm}$ and $0.6-\mathrm{mm}$ joint openings,

- $\mathrm{G}_{5}=$ central diameter of $3.5 \mathrm{~mm}$ and $0.0-\mathrm{mm}$ joint openings, and

- $\mathrm{G}_{6}=$ central diameter of $3.5 \mathrm{~mm}$ and $0.6-\mathrm{mm}$ joint openings.

The specimens were aligned in the metal matrix and fixed with Duralay II acrylic resin (DuraLay; Reliance Dental Mfg Co; Chicago, USA), respecting the joint openings.

After the union of the sectioned parts with acrylic resin, the specimens were invested in typeIV gypsum. Further, the resin was removed with a wire cutter following the gypsum crystallization. The metal adjacent to the gap was airborne-particle abraded at a pressure of $0.55 \mathrm{MPa}$ with $100 \mu \mathrm{m}$ aluminum oxide particles. ${ }^{15,20}$ Two laser-welding points were executed on opposite sides of each specimen to stabilize them. The gypsum was then removed, and the welding was completed with a Desktop laser machine (Dentaurum; Pforzhein, Germany) at a power of $360 \mathrm{~V} / 8 \mathrm{~ms}(1.5$ and $2.0 \mathrm{~mm}$ specimens) and $380 \mathrm{~V} / 9 \mathrm{~ms}$ ( $3.5 \mathrm{~mm}$ specimens). The focus and frequency were calibrated at 0 . For the $0.6-\mathrm{mm}$ joint opening groups, it was necessary to use Ti cp grade 2 wire (Dentaurum; Pforzhein, Germany) with a diameter of $0.4 \mathrm{~mm}$. The welding process was com-

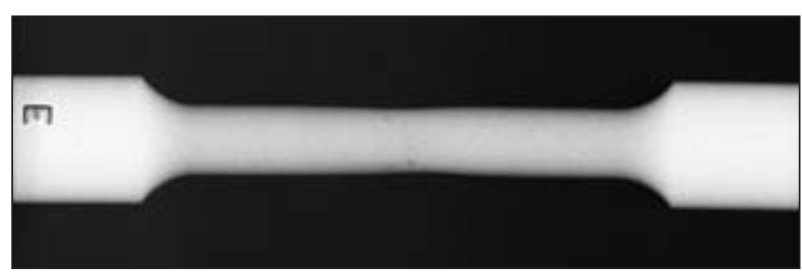

Figure 2 - Radiographic evidence of the presence of porosity in a $3.5-\mathrm{mm}$ specimen with a $0.6-\mathrm{mm}$ joint opening.

pleted by a trained and competent professional.

Subsequent to the welding process, the joints were finished and polished using a No. 5001 rubber polisher (Dedeco Dental; New York, USA) and titanium polishing paste (Tiger Brilliant Polier Paste; Dentaurum; Pforzheim, Germany). ${ }^{15}$ During the finishing process, the specimens' diameters were constantly verified with an electronic caliper (Starret; Microtec Instrumentos de Precisão M.E.; Sao Paulo, Brazil), assuring an accuracy rate of within $0.01 \mathrm{~mm} .^{15}$

Radiographs of the joints were taken with radiographic film (Ektaspeed Plus; Eastman Kodak; Rochester, NY, USA) to check for the presence of internal defects. The radiographic examination consisted of the exposure of the specimens to radiation $(90 \mathrm{KV}, 15 \mathrm{~mA}, 0.6$ seconds, at a distance of 10 to $13 \mathrm{~mm}$ ) using periapical film. ${ }^{15,17,18}$ The films were automatically processed. ${ }^{21}$ The radiographs were visually examined for the presence of pores in the joints, qualitatively (Figure 2). Those radiographs that permitted the viewing of any pores within the joint were classified as having presence $(\mathrm{P})$, although the pores per joint were not counted. The percentage of $\mathrm{P}$ was calculated, and the data were analyzed using a chi-square test $(\alpha=0.05)$.

\section{Results}

Table 1 shows the incidence of internal porosity presence $(\%)$ in the laser-welded joints according to specimen diameter and joint opening. For the $1.5-\mathrm{mm}$ specimens, when the joint had an opening of $0.0 \mathrm{~mm}$, a lower incidence of internal porosity was observed $(0 \%)$. This was significantly less ( $\mathrm{p}=0.0001)$ than that of the $0.6-\mathrm{mm}$ joint opening specimens $(40 \%)$. For the $2.0-\mathrm{mm}$ specimens, there was no statistical difference between the openings 
Table 1 - Presence of internal porosity (\%) in the joints as a function of joint opening and diameter of specimens.

\begin{tabular}{|c|c|c|c|c|}
\hline & & \multicolumn{3}{|c|}{ Internal porosity (\%) } \\
\hline \multicolumn{2}{|c|}{ Diameter (mm) } & 1.5 & 2.0 & 3.5 \\
\hline \multirow{3}{*}{ 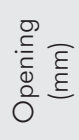 } & 0.0 & 0 & 50 & 70 \\
\hline & 0.6 & 40 & 60 & 50 \\
\hline & $(p=)$ & 0.0001 & 0.2008 & 0.0061 \\
\hline
\end{tabular}

Chi-squared test $(\alpha=0.05)$.

$(\mathrm{p}=0.2008)$. Conversely, a statistical difference $(p=0.0061)$ was found when the joint openings of the $3.5-\mathrm{mm}$ specimens were compared. The incidence of porosity was higher $(70 \%)$ when there was contact between the parts.

Figure 2 illustrates the internal porosity present in a $3.5-\mathrm{mm}$ specimen welded with a $0.6 \mathrm{~mm}$ joint opening.

\section{Discussion}

The presence of porosity in laser-welded joints was observed in Ti-6Al-4V structures. This finding corroborates those of Nuñez-Pantoja et al. ${ }^{15}$ In previous studies, ${ }^{10,16-18,22}$ authors reported that internal porosity could be observed in cast structures, allowing faulty ones to be discarded. Further, this method reportedly enabled the analysis or observation of secondary caries below installed frameworks. However, in another study, ${ }^{22}$ the same research group reportedly experienced difficulty when visually inspecting porosity in laser-welded joints. This finding is contradictory to the results of the present study (Figure 2) and to those of Nuñez-Pantoja et al. ${ }^{15}$ In both of these studies, the researchers observed internal pores in joints of specimens with central diameters of 1.5 and $2.0 \mathrm{~mm}$. These diameters are smaller than the $2.3-\mathrm{mm}$ diameter analyzed by Zavanelli et al. ${ }^{22}$ The incorrect processing of a radiographic film can lead to inaccurate radiographic analyses. Dilute processing solutions can generate radiographs with diminished contrast, ${ }^{21}$ which can make radiographic analysis of joints impractical. In order to obtain high-quality standardized radiographs, the films were automatically processed in this study. In clinical practice, this processing must be carried out using quality solutions to permit radiographic analysis. ${ }^{21}$
The low density of titanium alloys enables the indepth penetration of radiation in structures, allowing for the observation of porosity. ${ }^{10,15-18,22}$ The presence of internal porosity in laser-welded joints can occur due to inadequate laser beam penetration and gas seizure as a consequence of continuous argon spraying throughout the procedure. ${ }^{13-15,22,23}$ When the penetration depth of the laser beam is low, a greater internal void may be created. ${ }^{15,24}$ According to some authors, $7,13,23,24$ laser penetration is limited to $1.5 \mathrm{~mm}$ of depth, which may explain the higher incidence of internal porosity $(70 \%)$ in the $3.5-\mathrm{mm}$ juxtaposed welded specimens $(0.0-\mathrm{mm}$ joint openings) in this study.

The $0.6-\mathrm{mm}$ joint openings reduced the incidence of internal porosity in large specimens $(50 \%)$ in this study; however, in thin specimens $(1.5 \mathrm{~mm})$, the higher quantity of metal added led to an increased incidence of porosity (40\%). Generally, welded joints must protrude in such a way that they deposit very little filler metal to avoid gas arrestment and attenuate remainder distortions. ${ }^{15}$ This explains the smaller incidence $(0 \%)$ of internal voids in the 0.0 $\mathrm{mm}$ joints of thinner specimens $(1.5 \mathrm{~mm})$. However, when the penetration depth of the laser beam is insufficient, as in the $3.5-\mathrm{mm}$ specimen, the $0.6-\mathrm{mm}$ joint opening is recommended.

According to previous research, contact between parts, which is difficult to obtain clinically, is associated with the success of the union. ${ }^{7,915}$ However, in the present study, this relationship was not observed for the $3.5-\mathrm{mm}$ specimen, which corroborates the findings of Nuñez-Pantoja et al. ${ }^{15}$ Thus, if the welding of larger titanium frameworks is necessary in clinical practice, the joint parts should not be juxtaposed. For 2.0-mm specimens, there was no statistical difference between the joint openings analyzed $(\mathrm{p}=0.2008)$, which suggests that it is possible to weld at both distances in practice. However, NuñezPantoja et al. ${ }^{15}$ found differences in the fatigue resistance of these structures. They argued that it was necessary to laser-weld the $2.0-\mathrm{mm}$ specimens using the juxtaposition of parts design.

Within the limitations of this study, for structures with central diameters of $1.5 \mathrm{~mm}$ or less, the laser-welded joints must use juxtaposed sections. In 
larger specimens, different joint designs should be studied to improve laser-welded joint quality. ${ }^{15}$ For example, the " $X$ " design, which includes two adjacent joint surfaces that form the shape of the letter " $X$ " when juxtaposed, could circumvent the insufficient laser beam penetration depth. ${ }^{25}$ With this design, the center maintains the parts juxtaposed with a thin diameter, which permits the deep penetration of the laser beam. The periphery should then be welded, starting from the welding center up to the surface of the specimen, reducing the quantity of metal filler. ${ }^{15,25}$ This design would probably decrease the incidence of internal porosity.

\section{References}

1. Blackman R, Barghi N, Tran C. Dimensional changes in casting titanium removable partial denture frameworks. J Prosthet Dent. 1991 Feb;65(2):309-15.

2. Wang RR, Fenton A. Titanium for prosthodontic applications: a review of the literature. Quintessence Int. 1996 Jun;27(6):401-8.

3. Chai T, Chou CK. Mechanical properties of laser-welded cast titanium joints under different conditions. J Prosthet Dent. 1998 Apr;79(4):477-83.

4. Lygre H. Prosthodontic and adverse reactions: a critical review of the clinical and research literature. Acta Odontol Scand. 2002 Jan;60(1):1-9.

5. Faria AC, Rodrigues RC, Antunes RP, de Mattos Mda G, Rosa AL, Ribeiro RF. Effect of temperature variation on the cytotoxicity of cast dental alloys and commercially pure titanium. J Appl Oral Sci. 2009 Sep-Oct;17(5):421-6.

6. Sjögren G, Andersson M, Bergman M. Laser welding of titanium in dentistry. Acta Odontol Scand. 1988 Aug;46(4):24753.

7. Tambasco J, Anthony T, Sandven O. Laser welding in the dental laboratory: an alternative to soldering. J Dent Technol. 1996 May;13(4):23-31.

8. Wang RR, Chang CT. Thermal modeling of laser welding for titanium dental restorations. J Prosthet Dent. 1998 Mar;79(3):335-41.

9. Wang RR, Welsch GE. Joining titanium materials with tungsten inert gas welding, laser welding, and infrared brazing. J Prosthet Dent. 1995 Nov;74(5):521-30.

10. Guilherme AS, Henriques GE, Zavanelli RA, Mesquita MF. Surface roughness and fatigue performance of commercially pure titanium and Ti-6Al-4V alloy after different polishing protocols. J Prosthet Dent. 2005 Apr;93(4):378-85.

11. Taira M, Moser JB, Greener EH. Studies of Ti alloys for dental castings. Dent Mater. 1989 Jan;5(1):45-50.

\section{Conclusion}

Despite the limitations of this study, the juxtaposition of parts in laser-welded joints of Ti-6Al-4V structures seems to affect the percentage of radiographic porosity present, depending on the diameter of the joints. This influence was positive for $1.5-\mathrm{mm}$ specimens, but negative for $3.5-\mathrm{mm}$ specimens.

\section{Acknowledgements}

This study was supported by FAPESP (Grant No. 06/58816-2 and No. 07/51306-1) and NEODENT Indústria e Comércio de Materiais Dentários Ltda.

12. Liu J, Watanabe I, Yoshida K, Atsuta M. Joint strength of laser-welded titanium. Dent Mater. 2002 Mar;18(2):143-8.

13. Roggensack M, Walter MH, Böning KW. Studies on laser- and plasma- welded titanium. Dent Mater. 1993 Mar;9(2):104-7.

14. Watanabe I, Topham DS. Laser welding of cast titanium and dental alloys using argon shielding. J Prosthodont. 2006 MarApr;15(2):102-7.

15. Nuñez-Pantoja JM, Vaz LG, Nóbilo MA, Henriques GE, Mesquita MF. Effects of laser-weld joint opening size on fatigue strength of Ti-6Al-4V structures with several diameters. J Oral Rehabil. 2010 Jul 29. [Epub ahead of print].

16. Wang RR, Boyle AM. A simple method for inspection of porosity in titanium castings. J Prosthet Dent. 1993 Sep;70(3):2756.

17. Zavanelli RA, Henriques GEP. A simple method to porosity radiographic inspection in pure titanium castings. Rev ABO nac. 2001 Jun;9(3):165-6.

18. Nuñez JM, Takahashi JM, Henriques GE, Nóbilo MA, Consani RL, Mesquita MF. Radiographic inspection of porosity in pure titanium dumbbell castings. Gerodontology. 2010 May 26. [Epub ahead of print].

19. American Society for Testing and Materials International. Designation: E 8M - 04: Standard Test Methods for Tension Testing of Metallic Materials [Metric]. West Conshohocken: ASTM; 2004. 24 p.

20. Taylor JC, Hondrum SO, Prasad A, Brodersen CA. Effects of joint configuration for the arc welding of cast Ti-6Al-4V rods in argon. J Prosthet Dent. 1998 Mar;79(3):291-7.

21. Thornley PH, Stewardson DA, Rout PG, Burke FJ. Assessing the quality of radiographic processing in general dental practice. Br Dent J. 2006 May 13;200(9):515-9; discussion 503.

22. Zavanelli RA, Guilherme AS, Pessanha-Henriques GE, de Arruda Nóbilo MA, Mesquita MF. Corrosion-fatigue of laser-repaired commercially pure titanium and Ti-6Al-4V al- 
- Radiographic inspection of porosity in Ti-6Al-4V laser-welded joints

loy under different test environments. J Oral Rehabil. 2004 Oct;31(10):1029-34.

23. Berg E, Wagnere WC, Davik G, Dootz ER. Mechanical properties of laser-welded cast and wrought titanium. J Prosthet Dent. 1995 Sep;74(3):250-7.
24. Baba N, Watanabe I. Penetration deph into dental casting alloys by Nd:YAG laser. J Biomed Mater Res B Appl Biomater. 2005 Jan 15;72(1):64-8.

25. Zupancic R, Legat A, Funduk N. Tensile strength and corrosion resistance of brazed and laser-welded cobalt-chromium alloy joints. J Prosthet Dent. 2006 Oct;96(4):273-82. 